\title{
The Relationship between Language Proficiency Level and L2 Digital Literacy Self-efficacy: A Study of EFL University Students
}

\author{
https://doi.org/10.33806/ijaes2000.21.2.10
}

\author{
Nuha Abdullah Alsmari \\ Prince Sattam bin Abdulaziz University, KSA
}

\begin{abstract}
The evolving digitization of teaching and learning in higher education institutions requires students to be digitally literate (Miller 2015). Despite the echoes of being "digital natives" (Prensky 2001), many EFL students experience difficulties when locating, retrieving, evaluating, and synthesizing digital information at their disposal, especially when the information is in English. To this end, this study is conducted to scrutinize the relationship between EFL students' second language (L2) digital literacy skills and strategies (DLSs) self-efficacy and their English proficiency level. A total of 93 Saudi students majoring in English at Prince Sattam bin Abdulaziz University were surveyed for their English proficiency level and their abilities to use three major domains of digital literacy skills. The data were analyzed statistically using descriptive measures and ANOVA. The results revealed a significant positive correlation between English proficiency and L2 DLSs. Students with intermediate and upper-intermediate English levels displayed low efficacy in their abilities to navigate, evaluate, and synthesize online information compared to advanced English users. The study concluded that students with higher English proficiency are more responsive to digital literacy skills and can perform well in digitally enhanced environments than basic English users. Pedagogical implications and areas for future research are discussed.
\end{abstract}

Keywords: Digital literacy, English proficiency, L2 digital literacy skills, Saudi EFL learners, self-efficacy

\section{Introduction}

In a world where information and communication technologies (ICTs) are becoming increasingly pervasive and influential using English as the lingua franca of information and communication, there are a corresponding accelerated need to promote the second language and/or foreign language (L2) digital literacy skills (DLSs) to exploit language-specific web-based resources in a meaningful way, communicate efficiently in computer-mediated environments, and optimize second language acquisition (SLA). L2 Digital literacy is a set of complicated and integrated cognitive and technical skills that enable individuals to review and comprehend online information accurately to reconstruct data and introduce new knowledge (Okeji, Tralagba and Obi 2019). More importantly, L2 digital literacy involves the ability to navigate, locate, communicate, evaluate and synthesize information retrieved in multiple formats and language-specific texts (Digital Literacy Task Force 2013:2; Al Seghayer 2020; Gilster 1997). Given that ICTs and 
English language are inseparably interrelated and constantly interact with each other, L2 DLSs are an essential prerequisite to empowering learners with the 21stcentury literacies that will allow entrance into academic and workforce environments (Son, Robb and Charismiadji 2011; Son, Park and Park 2017).

Technology has transformed the way information is delivered in higher education institutions. Digital resources have become the predominant mode of delivery for course contents and tasks. Information search on the Internet is a core practice to complete course-related tasks and research projects. Son, Robb and Charismiadji (2011) contended that computer-assisted language learning (CALL) courses in EFL academic settings require an adequate digital literacy level for effective self-directed learning. Recent research has further established that digital literacy self-efficacy is a significant predictor of university students' academic success (Aharony and Gazit 2020). However, little attention has been paid to students' L2 digital literacy skills as if they were pre-given skills. The massive production of digital resources and the growing use of digital libraries play a supportive role in second language acquisition (SLA), forcing EFL students to move beyond the realm of traditional paper-based documents to digital formats (Gilbert 2017). This technological transformation requires learners to expand their digital competency to meet the current demands of education, interact with ICT tools and e-resources efficaciously, and function adequately in a complex digitally enhanced language learning environment.

Research studies within the fields of second language acquisition (L2) have postulated that computer-based technologies, if used efficiently, could have the power to accelerate the quality of teaching and learning foreign languages, especially in input-poor environments such as EFL contexts as it exposes learners to authentic learning instantiations relevant to their real-life communications (Gilbert 2017; Son, Robb, and Charismiadji, 2011). However, most studies focused on how online activities and social networks strengthen language learning without exploring the technical and cognitive skills needed to actively engage in those practices (Sawatdeenarunat 2014). While technology provides a plethora of possibilities for optimizing language learning, particularly for EFL learners, Son et al. (2017) argue that the determinants of meaningful and useful interaction within online environments are mainly dependent on the possession of solid L2 DLSs and practices. Considering the study context, Al Seghayer (2020) reported that Saudi EFL learners do not hold the necessary digital literacy skills to locate, evaluate, and synthesize information due to inadequate online-search skills, English deficiency, and lack of digital instruction. Thus, the daunting challenge that lies ahead for EFL learners is not only to enhance their English proficiency to manage and package focused information in the written mode (Aleraini 2020), but also to gain L2 digital literacy skills that will allow them to navigate websites, evaluate data for relevance and adequacy, and synthesize information to take advantage of these digital resources and expedite their English language acquisition. L2 Digital literacy is a functional literacy that will open doors for EFL learners to acquire other competencies and skills for academic and career success and achieve personal goals over time (Fraillon, Schulz and Ainley 2013). 
While there is increasingly extensive research on the first language (L1) digital literacy skills (see review: Sánchez-Caballé, Gisbert-Cervera and EsteveMon 2020), there is a dearth of research on second and/or foreign language (L2) students' digital literacy practices when navigating, synthesizing, and evaluating web-based information (Al Seghayer 2020; Gilbert 2017; Dashtestani and Hojatpanah 2020). This paucity of research is assumed to be the result of three postulations. First, learners of the current generations are believed to be digitally literate and technologically savvy and, therefore, accommodate themselves to handle emerging technologies without instruction. However, research has informed that students have insufficient digital competence as they know how to use technology for entertainment and not for learning and work (Sánchez-Caballé et al. 2020). Second, learners can transfer their L1 skills and apply them in L2/FL educational settings (Sawatdeenarunat 2014). Yet, the bulk of literature has reported that DLSs can only be developed through explicit instruction and training (Leu, Zawilinski, Forzani and Timbrell 2014). Besides, native English speakers use their L1 for Internet search, while ESL/EFL learners are often overwhelmed when confronted with websites containing English beyond their level of proficiency. Therefore, EFL learners tend to browse websites and generate key terms using their native language when attempting online tasks. This preference arises from their lack of sufficient English proficiency to efficiently conduct an L2 online search and limited online-search experience (Gilbert 2017). Third, the low level of digital literacy skills among EFL teachers constitutes a significant barrier to the successful application of digital learning (Dashtestani and Hojatpanah 2020). Teachers are more challenged as they lack the instructional tools to guide their learners in much richer and more complex technologically enhanced environments, requiring teacher education and professional development programs in L2 DLSs for effective digitization in the classroom (Leu, Kinzer, Coiro, Castek and Henry 2017).

Realizing this gap in the extant literature, this research's primary goal is to explore the impact of English proficiency on EFL learners' self-efficacy to perform L2 DLSs adequately. To this end, the purpose of the study is two-fold; (1) to investigate Saudi EFL students' self-efficacy in L2 DLSs pertaining to three major domains; online search strategies, critical evaluation skills, and productive synthesis skills among three English proficiency groups (intermediate; upperintermediate and advanced users of English); (2) to determine the statistical relationship between language proficiency and EFL learners' L2 digital literacy abilities, and whether English proficiency can contribute to good L2 DLSs. This study seeks to find answers to the following research questions:

1. What is the level of L2 digital literacy skills self-efficacy among intermediate, upper-intermediate, and advanced English proficiency Saudi EFL students?

2. Does Saudi EFL students' level of language proficiency affect their selfperceived L2 digital literacy skills? 
3. Is there any significant correlation between Saudi EFL students' English proficiency and their self-perceived L2 digital literacy skills?

\section{Literature review}

L2 DLSs are the $21^{\text {st }}$-century literacies that comprise a cluster of skills, strategies, dispositions, and additional social practices that enable individuals to perform broader computerized activities beyond mere computer skills such as word processing programs using the Internet or social media (Cardoso and Oliveira 2015). It is a self-directed process of using digital media to create texts and knowledge while partaking in a variety of online literacy measures including identifying essential issues, locating, communicating, critically evaluating, and synthesizing information to use it effectively for one's own goals (Leu et al. 2017). Similarly, Mutta, Pelttari, Salmi, Chevalier and Johansson (2014) conceptualize digital literacy as consisting of two major components. The first component involves technical competencies that assist users in their selection and use of digital technologies. The second component covers users' experience in online platforms and communication that are language-related, including reading, interpreting, analyzing, writing, viewing, etc. For the current study, L2 DLSs are readiness, selfefficacy, and developing non-native learners' digital skills to use English as an L2 to locate, understand, communicate, evaluate, and synthesize English online information effectively.

These new literacies draw upon foundational literacies needed for conventional paper-based reading and writing, such as word recognition, vocabulary size, language comprehension, inference, spelling, and other traditional reading competencies for textbooks and paper-based information (Leu et al. 2017). These core literacies represent the baseline toward mastering twenty-first century skills to conform to an online age's demands with rapidly changing information and communication technologies (ICTs). For EFL learners, being digitally competent is a more sophisticated process. They have to generate search terms, locate eresources, evaluate digital information, and produce new knowledge in a language they have not fairly mastered. Thus, the acquisition of digital literacy for EFL learners is two-fold. The first is to ensure that learners have good foundational literacies in L2, as the base upon which students can build more advanced competencies and discrete computer skills. The second is to enhance these skills by providing plenteous scaffolded opportunities to employ them in digital spaces. In this way, not only will academic learning objectives be achieved, but learners will also be professionally equipped to meet the advanced learning technologies and become digitally literates for the workplace.

The study is underpinned by the new literacy and competency theories, which were initiated to respond to the technological advancements and proliferation of Internet access (Leu et al. 2017). The traditional concept of literacy, which is the ability to read and write, has moved to a broader view of knowledge that identifies crucial digital skills, strategies, and dispositions vital for online search, comprehension, and communication in this digital era. Carretero, Vuorikari and 
Punie (2017) have produced one of the most popular and updated digital literacy frameworks. According to this framework, digital literacy encompasses five components: (1) data and information literacy; (2) communication and cooperation; (3) formation of digital content; (4) ethical skills; and (5) problemsolving. Data and information literacy involve the ability to navigate, locate, manage, and evaluate content exhibited in multiple formats on the Web. Communication and collaboration refer to the capability to communicate, collaborate, share, and socialize smoothly using digital technologies with other users of online platforms. Digital content formation covers the ability to develop, integrate, and edit online content in various formats (audio, video, text, etc.) by synthesizing relevant information. Ethical skills refer to the potential to apprehend the rules relating to copyrights and ownership in the network. Problem-solving entails the ability to identify needs, solve technical issues, and use modern technologies efficiently and creatively (Carretero et al. 2017). Thus, to be prepared for 21st-century literacies, EFL students need to acquire a plurality of competencies, starting with content literacy and technical qualifications and extending to consider the cognitive and sociocultural skills. These competencies will assist them in handling controversial issues better and in finding, comprehending, evaluating, implementing, and synthesizing digital information effectively (Sawatdeenarunat 2014).

While there is extensive research on L1 digital literacy skills, very few studies have been published on ESL/EFL students' digital literacy practices when navigating, synthesizing, and evaluating web-based information (Aharony and Gazit 2020; Al Seghayer 2020; Barlow-Jones and van der Westhuizen 2011; Mutta et al. 2014; Nizam, Musa and Wahi 2010; Sawatdeenarunat 2014). Nizam et al. (2010) initiated the first attempt to explore L2 DLSs of ten Malaysian EFL students as they engaged in course-related English tasks. The study assessed students' information literacy abilities while preparing speech outlines for a speaking course and their responses to an open-ended survey. Findings reported that students needed more knowledge and guidance to be effective informationliterate and achieve academic success, especially when the information is in English. It was evident that limited English proficiency adversely influences learners' abilities to self-direct their information search efficiently and critically assess e-resources. Likewise, Mutta et al. (2014) investigated information searching skills such as the use of sources, keywords, search terms, etc. among 50 university students' using their L1 compared to information seeking in L2 through Websearch tasks of varying complexity. The study has further examined the impact of developing students' awareness of information seeking in L2 as a part of digital competence in the academic context. Results demonstrated that searching for online information in L1 is faster than in L2. The pedagogical intervention of informationseeking in L2 has also had a positive impact on students' digital literacy.

In Thailand, Sawatdeenarunat (2014) carried out a study on 52 Thai EFL students' digital literacy practices when completing web-based course-related language tasks. The researcher used a think-aloud protocol to tap into the respondents' cognitive processes while browsing the Internet. Findings revealed 
that generating search terms, locating relevant information, and evaluating search results were significant challenges in conducting a web search. Students' responses were often copied from the actual online text, given the lack of English proficiency, difficulty in synthesizing information, and undeveloped online reading strategies. In the Saudi context, Al Seghayer (2020) pioneered the first attempt to explore sixty EFL students' self-perceived abilities in L2 digital literacy skills compared to their practical performance. Participants' self-assessment was measured through a crosssectional survey, examining students' information searching skills, critical evaluation skills, and information syntheses skills. The practical use of students' L2 DLSs was captured through a screen recording software while performing several real-time search activities in an online-based setting. Findings showed a low selfefficacy among EFL students in performing L2 DLSs concerning locating, evaluating, and synthesizing digital resources. These self-reported abilities were compatible with their practical online performance, which was significantly flawed. The researcher attributed EFL students' low performance when conducting online tasks to English language deficiency and inadequate search skills.

From another perspective, Barlow-Jones and Van der Westhuizen (2011) explored the extent to which critical thinking skills, socio-economic status, and English proficiency contribute to the academic success of 175 students in an information technology course. Results indicated that the identified factors played an influential role in students' digital literacy levels in the class. There was a correlation between students' level of English and their success in the information technology course. Similarly, Aharony and Gazit (2020) examined whether personality traits involving openness to experience, motivation, and cognitive appraisals of 136 students influence their information literacy self-efficacy. Results have reported that the variables of openness to experience, motivation, and cognitive appraisals were significant predictors of students' abilities to seek online information and evaluate digital content.

The literature on digital literacy has pointed out several factors that may influence students' abilities to acquire and use DLSs in L2. These may include educational policies and language barriers (Sawatdeenarunat 2014), Internet access and socio-economic level (Korucu, Yucel, Gundogdu and Gencturk 2016), problem solving and strategic skills (Gutiérrez and Serrano 2016), critical thinking skills (Barlow-Jones and Van der Westhuizen 2011), etc. Despite reporting the influence of English proficiency on students' faculties to search, communicate, evaluate and synthesize information as part of their L2 digital literacy skills as mentioned in the above literature, there is no study that has established if there is a significant association between language proficiency and L2 DLSs. This study contributes to the current literature by establishing the first evidence of the correlation between English proficiency and EFL learners' self-perceived L2 DLSs, and whether students with a higher level of English proficiency have better L2 digital literacy abilities.

\section{Methodology \\ 3.1 Participants}


The sample consisted of 93 Saudi female EFL students majoring in English at Prince Sattam bin Abdulaziz University. Their age ranged from 20 to 25, with a mean of 21.47. Participants' selection was based on their language proficiency level. Based on the test scores of the Standardized Test of English Proficiency (STEP), participants were assigned to three English proficiency groups: intermediate English users $(\mathrm{n}=30)$, upper-intermediate English users $(\mathrm{n}=36)$, and advanced English users $(\mathrm{n}=27)$ groups. Independent and advanced English users were selected to ensure a proper English level that would allow participants to partake in the study. All participants had studied English formally during their primary, intermediate, and secondary schools for at least nine years before joining the 4-year English undergraduate program. None of them has reported studying in an English-speaking country. Data on participants' demographic information, web search experience, and online search skills were also gathered. Table 1 presents a summary of the self-reported demographics of the sample.

Table 1. Participants' characteristics

\begin{tabular}{|c|c|c|c|c|}
\hline \multirow{2}{*}{ Age } & $20-22$ years & $23-25$ years & & \\
\hline & $34 \%$ & $66 \%$ & & \\
\hline \multirow{2}{*}{$\begin{array}{c}\text { Number of hours } \\
\text { invested } \\
\text { browsing the } \\
\text { Web daily } \\
\end{array}$} & $\begin{array}{c}\text { More than } 4 \\
\text { hours }\end{array}$ & 3-4 hours & 1-2 hours & $\begin{array}{c}\text { Less than } 1 \\
\text { hour }\end{array}$ \\
\hline & $57 \%$ & $31.6 \%$ & $10 \%$ & $2 \%$ \\
\hline \multirow{2}{*}{$\begin{array}{c}\text { How do you rate } \\
\text { your experience } \\
\text { using web } \\
\text { engines? }\end{array}$} & Excellent & Good & Poor & \\
\hline & $32 \%$ & $51 \%$ & $17 \%$ & \\
\hline \multirow{2}{*}{$\begin{array}{c}\text { How do you rate } \\
\text { your experience } \\
\text { of information } \\
\text { seeking on the } \\
\text { web? }\end{array}$} & Excellent & Good & Poor & \\
\hline & $30 \%$ & $56 \%$ & $14 \%$ & \\
\hline \multirow{2}{*}{$\begin{array}{l}\text { Rate your } \\
\text { potential to } \\
\text { assess digital } \\
\text { resources. }\end{array}$} & Excellent & Good & Poor & \\
\hline & $22 \%$ & $59 \%$ & $19 \%$ & \\
\hline
\end{tabular}

\subsection{Instruments}

Two quantitative instruments were used to address the questions of the study. The first is the Standardized Test of English Proficiency (STEP). It is a verified testing instrument designed in accordance with the Common European Framework of Reference for Languages to assess English language proficiency for students attempting to apply for teaching positions, higher education, admissions, 
businesses, or any other professional fields. The test consists of 100 questions measuring reading comprehension, sentence structure, listening comprehension, and composition analysis. The second is a multidimensional L2 DLSs questionnaire addressing students' self-efficacy abilities in three major digital literacy domains. The survey was developed by Al Seghayer (2020) and modified for the current study. It consists of 27 items involving three subscales: (1) information-search skills and strategies (19 items), (2) evaluating online information critically (4 items), and (3) synthesizing digital resources strategies (4 items), which require participants to respond to a five-point Likert scale, ranging from 5 (completely able to do to) 1 (completely unable to do). It aimed at assessing both lower-order skills required for locating and navigating Internet data and higher-order cognitive strategies needed for analyzing and synthesizing online content objectively. The instrument represents typical Internet usage and uses the ability measurement of perceived literacy skills. The reliability estimation was $.936(.91, .85$ and .87 for each subscale respectively). After modifications, the instrument was piloted with 20 EFL students from the same population, and the reliability index was re-tested using Cronbach's alpha, which indicated a high level (.90).

\subsection{Procedure}

The study used a quantitative correlational design to examine whether the level of EFL students' language proficiency affects their abilities to use L2 digital literacy skills and strategies. Data were collected in two phases. In the first phase, the researcher sent an email invitation to English majors from level four and above, including a brief description of the study and requesting them to voluntarily and confidentially participate in the study. Upon their consent, a date was set for 122 participants to conduct the STEP test. The participants were allocated two hours and fifteen minutes to perform the test in the college hall, along with the demographic survey. After initial data screening, 93 respondents were recruited for the study according to their test scores. Based on the STEP assessment criteria, students who scored between (60-67) were categorized as intermediate English users $(\mathrm{n}=30)$, students who scored between (75-85) were classified as upperintermediate English users $(\mathrm{n}=36)$, and students who scored between (86-97) were categorized as advanced English users $(n=27)$. Participants of elementary English proficiency were excluded from the study due to their inappropriate language proficiency. In the second phase, the L2 DLSs questionnaire was distributed online among the selected respondents. The questionnaire was completed within 15-20 minutes. The researcher was available to answer any inquiry during the datacollection process.

\subsection{Data analysis}

Data analyses were performed using the Statistical Package for the Social Sciences (SPSS version 25). Descriptive statistics containing means, standard deviations, and percentages were employed to describe the participants' demographic information, responses to the STEP test, and the 27 items on the five-point Likert scale, ranging from 1 (completely unable to do) to 5 (completely able to do) among the three 
subcategories of digital literacy skills. Descriptive statistics were used to provide a report of participants' self-perceived DLSs and English proficiency, and thus answer the first research question. ANOVA test was performed to determine significant differences in proficiency levels and mean subscale scores between the three proficiency groups. Pearson correlations were used to examine the relationship between the variables (DLSs self-efficacy and English proficiency) in an attempt to answer the third research question.

\section{Results}

\subsection{Differences in English proficiency levels according to participants' STEP scores}

According to their scores in the STEP test, to measure participants' language proficiency, descriptive statistics were run to assign students into three English proficiency levels. As displayed in Table 1, test scores ranged from 60 to 97 points, and thus students were distributed to three English proficiency groups. Students who scored between 60-67 with an average of 79.94 were regarded as intermediate English users. Students who scored between 75-85 with an average of 61.8 were considered upper-intermediate English users. Students who scored between 86-97 with an average of 92.8 were designated advanced English users.

Table 1. Distribution of the participants into three English proficiency levels

\begin{tabular}{|c|c|c|c|c|}
\hline $\begin{array}{c}\text { STEP Score } \\
\text { Range }\end{array}$ & Proficiency level & $\begin{array}{c}\text { No. of } \\
\text { students }\end{array}$ & Mean & \% \\
\hline $60-67$ & Intermediate & 30 & 79.9 & $32.25 \%$ \\
\hline $75-85$ & $\begin{array}{c}\text { Upper- } \\
\text { intermediate }\end{array}$ & 36 & 61.8 & $38.70 \%$ \\
\hline $86-97$ & Advanced & 27 & 92.8 & $29.03 \%$ \\
\hline
\end{tabular}

ANOVA was conducted to see if there were statistically significant differences in the participants' English proficiency according to their assigned levels. Table 2 shows that there was a significant difference between participants' English ability ( $\mathrm{F}=946.357, \mathrm{P}<.000)$. This result serves the study's purpose, which aims to compare different proficiency groups in terms of their L2 DLSs.

Table 2. Group comparison in terms of English proficiency

\begin{tabular}{|c|c|c|c|c|c|}
\hline Source & SS & df & MS & F & Sig. \\
\hline $\begin{array}{c}\text { Between } \\
\text { groups }\end{array}$ & 13992.5369 & 2 & 6996.26846 & 946.357412 & .000 \\
\hline $\begin{array}{c}\text { Within } \\
\text { groups }\end{array}$ & 665.355556 & 90 & 7.39283951 & & \\
\hline Total & 14657.8925 & 92 & & & \\
\hline
\end{tabular}

\subsection{L2 DLSs among intermediate, upper-intermediate, and advanced EFL students}


Descriptive statistics were computed on participants' responses in the three main domains of DLSs. As shown in Table 3, the mean scores of advanced proficiency respondents were relatively higher, with a total mean of 3.96 than their counterparts. The upper-intermediate proficiency respondents were moderate with a total compromise of 2.52 whereas the intermediate proficiency group was low, with a total mean of 2.00. This indicates that advanced language learners have more L2 digital literacy abilities than students with intermediate and upper-intermediate English levels.

Using the average score of each participant on the 27 items, most intermediate-English-level respondents had a value of less than 2.5 , referring to the undecided rate. This calculation suggests that students with intermediate English level have insufficient abilities to use L2 DLSs as a fulfillment competency to support their digital learning. The lowest mean scores were reflected in their selfperceived efficacy to evaluate online information critically and synthesize digital resources, 1.93 and 1.98, respectively. The majority of upper-intermediate English respondents $(61.11 \%)$ had a score below 3 , whereas the rest $(38.88 \%)$ had a score above 3 , indicating moderate digitally literate students. On the contrary, students with advanced English levels had shown, to some extent, a comprehensive knowledge covering the three domains of digital literacy skills. Most respondents had a score above 3.5, and the rest of the sample (33.33\%) had scored four and above.

Among all L2 DLSs sub-scales, the mean score of information-search skills and strategies was the highest $(\mathrm{M}=2.17 ; 2.63 ; 3.93)$ among the three groups. However, the three subscales' lowest mean score went for a critical evaluation of online information with an average score of 1.93, 2.41 and 3.79 for the intermediate, upper-intermediate and advanced learners, respectively.

Table 3. Descriptive statistics of DLSs sub-scales by different proficiency Levels

\begin{tabular}{|c|c|c|c|c|c|c|c|}
\hline Groups & No & Subscale & M & SD & Min & Max & $\begin{array}{c}\text { Overall } \\
\text { Mean }\end{array}$ \\
\hline \multirow{3}{*}{$\begin{array}{l}\text { Intermediate } \\
\text { users }\end{array}$} & \multirow{3}{*}{30} & $\begin{array}{l}\text { Information- } \\
\text { search skills and } \\
\text { strategies }\end{array}$ & 2.17 & 0.292 & 1.53 & 2.4 & \multirow{3}{*}{2.00} \\
\hline & & $\begin{array}{l}\text { Evaluating online } \\
\text { information } \\
\text { critically }\end{array}$ & 1.93 & 0.354 & 1.53 & 2.2 & \\
\hline & & $\begin{array}{l}\text { Synthesizing } \\
\text { digital resources }\end{array}$ & 1.98 & 0.023 & 2.16 & 2.2 & \\
\hline $\begin{array}{c}\text { Upper- } \\
\text { intermediate } \\
\text { users }\end{array}$ & 36 & $\begin{array}{l}\text { Information- } \\
\text { search skills and } \\
\text { strategies }\end{array}$ & 2.63 & 0.101 & 2.27 & 2.63 & 2.52 \\
\hline
\end{tabular}




\begin{tabular}{|c|c|c|c|c|c|c|c|}
\hline & & $\begin{array}{l}\text { Evaluating online } \\
\text { information } \\
\text { critically }\end{array}$ & 2.41 & 0.115 & 2.41 & 2.61 & \\
\hline & & $\begin{array}{l}\text { Synthesizing } \\
\text { digital resources }\end{array}$ & 2.47 & 0.147 & 2.47 & 2.75 & \\
\hline \multirow{3}{*}{$\begin{array}{l}\text { Advanced } \\
\text { users }\end{array}$} & \multirow{3}{*}{27} & $\begin{array}{l}\text { Information- } \\
\text { search skills and } \\
\text { strategies }\end{array}$ & 3.96 & 0.144 & 3.48 & 4.11 & \\
\hline & & $\begin{array}{l}\text { Evaluating online } \\
\text { information } \\
\text { critically }\end{array}$ & 3.79 & 0.100 & 3.29 & 4 & \multirow[t]{2}{*}{3.96} \\
\hline & & $\begin{array}{l}\text { Synthesizing } \\
\text { digital resources }\end{array}$ & 3.93 & 0.439 & 3.81 & 4.07 & \\
\hline
\end{tabular}

To examine whether there were any significant differences between groups in their use of L2 DLSs, an ANOVA was performed. As displayed in Table 4, findings demonstrated substantial differences between the three English proficiency groups regarding their self-efficacy to use L2 DLSs in all domains surveyed. Specifically, there were significant differences between all groups in their abilities to look for online data $(\mathrm{F}=237.169, \mathrm{P}<.000)$, to evaluate online information critically ( $\mathrm{F}=126.52$, sig. $<.000)$, and to synthesize digital resources $(\mathrm{F}=54.82$, $\mathrm{P}<.000$ ). This may indicate that L2 DLSs are positively affected by participants' English mastery.

Table 4. ANOVA results of DLSs subscales by groups of different proficiency Levels

\begin{tabular}{|c|c|c|c|c|c|c|}
\hline Sub-scale & Source & SS & df & $\mathrm{MS}$ & $\mathrm{F}$ & Sig \\
\hline \multirow{3}{*}{$\begin{array}{l}\text { Information- } \\
\text { search skills } \\
\text { and } \\
\text { strategies }\end{array}$} & $\begin{array}{l}\text { Betwee } \\
n \text { groups }\end{array}$ & $\begin{array}{c}40.026238 \\
5\end{array}$ & 2 & 20.0131192 & \multirow{3}{*}{$\begin{array}{c}237.16930 \\
3\end{array}$} & \multirow{3}{*}{$\begin{array}{c}.00 \\
0\end{array}$} \\
\hline & $\begin{array}{l}\text { Within } \\
\text { groups }\end{array}$ & 4.55669611 & 54 & 0.08438326 & & \\
\hline & Total & $\begin{array}{c}44.582934 \\
6 \\
\end{array}$ & 56 & & & \\
\hline \multirow{3}{*}{$\begin{array}{l}\text { Evaluating } \\
\text { online } \\
\text { information } \\
\text { critically }\end{array}$} & $\begin{array}{l}\text { Betwee } \\
\text { n groups }\end{array}$ & $\begin{array}{c}8.8060526 \\
7\end{array}$ & 2 & 4.40302633 & \multirow{3}{*}{$\begin{array}{c}126.52293 \\
7\end{array}$} & \multirow{3}{*}{$\begin{array}{c}.00 \\
0\end{array}$} \\
\hline & $\begin{array}{l}\text { Within } \\
\text { groups }\end{array}$ & 0.313202 & 9 & 0.03480022 & & \\
\hline & Total & 9.11925467 & 11 & & & \\
\hline \multirow{3}{*}{$\begin{array}{l}\text { Synthesizin } \\
\text { g digital } \\
\text { resources }\end{array}$} & $\begin{array}{c}\text { Betwee } \\
\text { n groups }\end{array}$ & 6.256664 & 2 & 3.128332 & \multirow{3}{*}{$\begin{array}{c}54.826587 \\
8\end{array}$} & \multirow{3}{*}{$\begin{array}{c}.00 \\
0\end{array}$} \\
\hline & $\begin{array}{l}\text { Within } \\
\text { groups }\end{array}$ & 0.513528 & 9 & $\begin{array}{c}0.05705866 \\
7 \\
\end{array}$ & & \\
\hline & Total & 6.770192 & 11 & & & \\
\hline
\end{tabular}




\subsection{Relationship between English proficiency and L2 DLSs}

In order to confirm whether there were any correlations between participants' English mastery and their self-report digital literacy skills and strategies, the Pearson correlation was computed. As indicated in Table 5, the calculations revealed that English proficiency was significantly and positively correlated with the overall use of L2 DLSs. Advanced English level was the most strongly correlated to L2 DLSs $(\mathrm{r}=.637, \mathrm{P}<.000)$. There was also a strong positive relationship between intermediate $(\mathrm{r}=.529, \mathrm{P}<.003)$ as well as upper-intermediate English levels $(\mathrm{r}=.521, \mathrm{P}<.001)$ and L2 DLSs. Hence, the higher students' English mastery is, the higher their DLSs self-efficacy capabilities. English proficiency is a significant predictor of L2 digital literacy skills and abilities.

Table 5. Pearson's correlations between L2 DLSs and language proficiency level

\begin{tabular}{|c|c|c|c|c|}
\hline \multicolumn{2}{|c|}{} & $\begin{array}{c}\text { Intermediate } \\
\text { English level }\end{array}$ & $\begin{array}{c}\text { Upper- } \\
\text { intermediate } \\
\text { English level }\end{array}$ & $\begin{array}{c}\text { Advanced } \\
\text { English level }\end{array}$ \\
\hline \multirow{2}{*}{$\begin{array}{c}\text { L2 } \\
\text { DLSs }\end{array}$} & $\begin{array}{c}\text { Pearson } \\
\text { Correlation }\end{array}$ & $.529 * *$ & $.512 * *$ & $.637 * *$ \\
\cline { 2 - 5 } & Sig. (2-tailed) & 0.003 & 0.001 & 0.000 \\
\hline$* * p<.01$ & \multicolumn{4}{|l}{} \\
\hline
\end{tabular}

\section{Discussion}

The present study sought to determine; (1) the self-efficacy of L2 digital literacy skills and strategies among Saudi female English majors, (2) the level of their English proficiency, and (3) the relationship between participants' self-perceived L2 DLSs and English proficiency. Major findings have reported that groups with different proficiency levels exhibited variant L2 digital literacy abilities. Students with advanced English levels have higher L2 DLSs than intermediate and upperintermediate users of English. Statistically, the level of English proficiency positively influences EFL students' abilities to locate, evaluate, and synthesize digital resources efficiently. This conclusion runs parallel with previous studies asserting the impact of English proficiency on EFL learners' digital literacy abilities (Nizam et al. 2010; Barlow-Jones and Van der Westhuizen 2011; Mutta et al. 2014; Sawatdeenarunat 2014; Al Seghayer 2020). The current study moves beyond earlier studies by examining and establishing the statistical correlation between EFL students' self-efficacy in L2 DLSs and their English proficiency. English proficiency was found to be a significant predictor of L2 digital literacy skills and abilities.

Among the three DLSs domains, critical evaluation of online information was perceived as the most challenging task, as seen in each subscale's composite score. Students of the three proficiency groups indicated a low level of performance, particularly when distinguishing biased and unbiased data and assessing its authenticity and reliability. The second domain identified as the most difficult was synthesizing digital resources, particularly when contrasting and integrating online information to produce a new output. This can partially be due to inadequate 
English language proficiency, which may, on the one hand, adversely affect students' ability to read and comprehend information at high levels and interact appropriately with the wide variety of digital texts. On the other hand, online information search requires higher-order cognitive skills like searching, analyzing, evaluating, and synthesizing, which are all complex processes primarily when conducted in a foreign language. This result goes in line with the findings of Mutta et al. (2014), Sawatdeenarunat (2014), Leu et al. (2017), and Al Seghayer (2020). Their EFL students demonstrated low self-efficacy abilities when carrying out the three domains of L2 DLSs and their subskills due to inadequate English proficiency and insufficient searching skills to deal with online environments' intricacy. The studies have concluded that EFL students need training and instruction in information-seeking strategies and critical thinking skills to assist them when navigating and evaluating web resources in technology-rich environments.

\subsection{Pedagogical implications and limitations}

The findings of this study bear significant pedagogical implications for the teaching and learning environment. First, given that learning is shifting towards digital-based environments, EFL learners need more training and guidance to become more competent information users and digitally literate primarily when the information is delivered in English. They must also be aware that obtaining L2 DLSs involves a set of cognitive processes, critical thinking skills, and digital literacy strategies. They should be able not only to read and comprehend information but also to analyze, test, evaluate, and reconstruct them for educational purposes. The integration of L2 digital literacies into pedagogy specific for EFL contexts is critical to empower students with the means to utilize a wide range of technologies collaboratively, creatively, and critically to support their life-long learning. Students equipped with L2 DLSs are capable of achieving more learning outcomes than traditional face-to-face classes. Developing digital literacy curricular will further provide a theoretical guide for EFL teachers to best instruct, model, and practice digital literacies. It will also offer the support needed for students who work in complex and unbounded virtual settings using a language that they have not yet mastered.

Second, EFL students are required to accelerate their English competence as it is the lingua franca of information and science as well as traditional reading literacies. English proficiency is an important mediator to help EFL learners interpret rich web texts on the Internet, acquire information independently, and communicate and synthesize knowledge. Accordingly, it is suggested that EFL teachers should pay more attention to foster EFL students' language proficiency and self-directed learning skills. A combined instruction between English language and digital literacies is essential to prepare students for the $21^{\text {st }}$-century literacy needed for success in university, career, and life.

Third, initiatives must be taken to conduct teacher education programs that promote comprehensive conceptual knowledge of the effective L2 digital literacy practices within online platforms to assist EFL students' growth of those required literacies. Pre-service teachers need to be familiar with the current technologies, 
navigate online information retrieved in multiple formats, contrast, and evaluate digital resources according to specific characteristics. In-service teachers are supposed to incorporate digital literacy practices into their instructional curricular to offer richer and more dynamic learning opportunities for their students to practice DLSs. They can use a blended form of teaching, which integrates conventional face-to-face instruction with computer-based learning to develop students' digital literacy.

Fourth, educational institutions must recognize L2 digital literacy's fundamental value in English to student development, academic success, and future work competition. This acknowledgment entails implementing digital curricular inside classrooms and being proactive (re)examining policies, practices, and theories of digital literacies within foreign language education.

The present study has some limitations which may open new horizons for future research. First, while the study population was a convenient sample of Saudi English majors, extending the sample to diverse contexts and educational fields could yield divergent results. Second, the selection was confined to female students, as the study was carried out in girls' college. Future research may scrutinize gender disparities, which may hold different outcomes. It is also possible to examine the critical digital literacy skills among EFL teachers in comparison to students, which may lead to different results and accurate pedagogical decisions. Third, although the study findings present concrete evidence of the correlation between English proficiency and L2 digital literacy abilities, including a broader range of English proficiency levels and a larger sample could contribute to better generalization. Fourth, the study design, as mainly quantitative, could also prohibit any generalizability to wider populations. Additional research may consider a combination of qualitative and quantitative tools, including think-aloud protocols, online interactive behaviors, observational reports. Finally, further investigations might explore the interaction among different variables such as age, aptitude, educational level, institutional factors, pedagogical intervention, and L2 DLSs as well as the influence of possible factors such as socio-economic factors, Internet access, and educational policies.

In sum, this research contributes to knowledge in the field of EFL education by enhancing our understanding of how language competence influences EFL students' use of digital literacies to search, evaluate and synthesize online information, and thereby pinpoint some of the obstacles that hinder online literacies which became central for modern education and self-directed learning. Based on students' feedback, respondents with a low level of English proficiency selfreported difficulty practicing L2 DLSs and vice versa. In this sense, EFL teachers and decision-makers in higher education institutions should take a step toward adopting and integrating L2 digital literacy pedagogy into formal classrooms and promoting EFL students' language proficiency. 
Nuha Abdullah Alsmari

Prince Sattam bin Abdulaziz University, KSA

ORCID Number: 0000-0002-9121-0868

E-mail: n.alsmari@psau.edu.sa

\section{References}

Aharony, Noa, and Tali Gazit. (2020). 'Students' information literacy selfefficacy: An exploratory study'. Journal of Librarianship and Information Science, 52(1), 224-236.

Aleraini, Nadiah. (2020). 'Knowledge of English focus constructions by Saudi learners of English: Usage-based approach'. International Journal of Arabic-English Studies, 20 (1), 143-170.

Al Seghayer, Khalid. (2020). 'Investigating the adequacy of EFL learners' L2 digital literacy skills, consistency of self-assessed competence, and actual performance'. International Journal of Computer-Assisted Language Learning and Teaching (IJCALLT), 10(2), 1-22.

American Library Association. (2013). Digital literacy, libraries, and public policy: Report of the office for information technology policy's digital literacy task force. (Retrieved January, 20, 2015).

Barlow-Jones, Glenda and Duan van der Westhuizen. (2011). 'Situating the student: factors contributing to success in an Information Technology course'. Educational Studies, 37(3), 303-320.

Carretero, Stephanie, Riina Vuorikari and Yves Punie. (2017). The digital competence framework for citizens. Publications Office of the European Union.

Cardoso, Paula Alexandra and Nuno Ricardo Oliveira. (2015, March). 'Scholars' use of digital tools: Open scholarship and digital literacy'. In Proceedings of the 9th International Technology, Education and Development Conference, INTED2015 proceedings, pp. 5756-5763.

Education \& Training Evaluation Commission. (2021). Standardized test for English proficiency (STEP). (Retrieved on 14 August, 2020).

Fraillon, Julian, Wolfram Schulz and John Ainley. (2013). International computer and information literacy Study: Assessment framework. International Association for the Evaluation of Educational Achievement. Amsterdam: IEA.

Gilbert, John. (2017). 'A study of ESL students' perceptions of their digital reading'. The Reading Matrix: An International Online Journal, 17(2), 179-195.

Gilster, Paul and Glister, Paul. (1997). Digital literacy. New York: John Wiley.

Prensky, Marc R. (2010). Teaching digital natives: Partnering for real learning. Corwin press. 
Korucu, Agah Tugrul., Ahmet Yucel, Mustafa Gundogdu and Tarik Gencturk. (2016). 'Investigation the technology usage level of teacher candidates'. Participatory Educational Re-search, 3(1), 14-21.

Leu, Donald., Lisa Zawilinski, Elena Forzani and Nicole Timbrell. (2014). 'Best practices in teaching the new literacies of online research and comprehension'. Best practices in literacy instruction, 343-364.

Leu, Donald., Charles Kinzer, Julie Coiro, Jill Castek and Laurie Henry. (2017). 'New literacies: A dual-level theory of the changing nature of literacy, instruction, and assessment'. Journal of Education, 197(2), 1-18.

Miller, Andrew. (2015). 'On paper, in person, and online: A multi-literacies framework for university teaching'. Journal of Academic Language and Learning, 9(2), A19-A31.

Mutta, Maarit., Sana Pelttari, Leena Salmi, Aline Chevalier and Johansson, Marjut. (2014). 'Digital literacy in academic language learning contexts: Developing information-seeking competence'. Digital literacies in foreign and second language education, 12, 240-258.

Nizam, Azwan Shaiza. (2010). 'Information literacy abilities in ESL classrooms'. Asean Journal of Teaching and Learning in Higher Education (AJTLHE), 2(1), 52-65.

Okeji, Chukwuma Clement, Eriye Chris Tralagba and Ifeyinwa Calista Obi. (2019). 'An investigation of the digital literacy skills and knowledge-based competencies among librarians working in university libraries in Nigeria'. Global Knowledge, Memory and Communication.

Sánchez-Caballé, Anna, Mercè Gisbert-Cervera and Francesc Esteve-Mon. (2020). 'The digital competence of university students: a systematic literature review'. Aloma: Revista de Psicologia, Ciències de l'Educació $i$ de l'Esport, 38(1).

Sawatdeenarunat, Sirinut. (2014). Conceptualizing online literacies an investigation into Thai EFL students' web-based research practices (Doctoral dissertation).

Son, Jeong-Bae, Thomas Robb and Charismiadji. Indra. (2011). 'Computer literacy and competency: A survey of Indonesian teachers of English as a foreign language'. Computer-Assisted Language Learning Electronic Journal (CALL-EJ), 12(1), 26-42.

Son, Jeong-Bae, Sang-Soon Park and Moonyoung Park. (2017). 'Digital literacy of language learners in two different contexts'. JALT CALL Journal, 13(2), 77-96.

Dashtestani, Reza. and Shamimeh Hojatpanah. (2020). 'Digital literacy of EFL students in a junior high school in Iran: voices of teachers, students and ministry directors'. Computer Assisted Language Learning, 1-31. 